DOI 10.22363/2312-8631-2017-14-4-399-405

UDK 378

\title{
AMERICAN SLANG: DIACHRONIC ANALYSIS
}

\author{
V.I. Nardyuzhev ${ }^{1}$, I.V. Nardyuzhev ${ }^{2}$, V.E. Marfina ${ }^{1}$, I.N. Kurinin ${ }^{1}$ \\ ${ }^{1}$ Peoples' Friendship University of Russia \\ Miklukho-Maklaya str., 6, Moscow, Russia, 117198 \\ ${ }^{2}$ Software development department, JSC "The Seventh Continent" \\ Building 21, MKAD 47, v. Govorovo, Moscow, Russia, 142784
}

\begin{abstract}
This work is devoted to a diachronic analysis of American slang. These days the English language became a global language, and its American variant strongly influences the international norm. To use and understand a language properly, one should not forget about its slang units. Being a significant part of a language, reflecting the culture and history, slang changes with years. To bridge a generation gap diachronic analysis is a research of great importance.
\end{abstract}

Key words: slang, American slang, American English, diachrony, diachronic analysis, Corpus of Historical American English

Introduction. Slang is an important part of any language. New slang words constantly occur in our everyday routine. Some words have a short life - they can live a day, a week, a month and then they become outdated. Other words live a long life since they cannot be replaced. Slang can be a reflection of fashion, music, literature, politics and history. Sometimes these words can be called symbols of an epoch. That is why it is very important to analyze the development of slang in different generations [2;3].

The frequency of usage of some elements and phenomena is coming reduced, and it happens that some of them completely disappear, while others are beginning to appear more frequently than before. Changes of the language occur for various reasons, but most of all take their origin in psychological, social and cultural facts. The identification, description and interpretation of the language changes over time are the problems of diachronic study $[1 ; 4]$.

The tasks of identifying and researching the sources of youth slang, that can be characterized by its fast speed of changing, and computer slang, the development of which is due to the rapid development of modern computer, cloud, mobile and Internet technologies, were considered and described in the following papers [5; 6]. Less studied issues of the use of American slang in the English language and its analysis in time are reflected in this article. The relevance of this study is also due to the fact that in accordance with the educational standards of higher education, an important element of the information culture of a modern student of linguistics, focused on translation activity, is his ability to provide oral, written, simultaneous translation of texts and speeches that contain different types of slang. 
The purpose of this article is to analyze changes of American slang in time. The problem of diachronic analysis of changes of American slang from the middle of the XIX century to the present day was considered. The practical value of the work consists in the fact that its results can be applied to clarify the methodology of studying the phenomenon of American slang in time, based on the elaborated corpuses. These results can be used while teaching English, in classes on scientific and technical translation, in developing recommendations for a workshop in the teaching process for students of linguistics [7].

Slang is an important part of every language, but in our work we decided to concentrate on American English. It acquired a status of an especially internationally important language because of the influence that the United States have on the whole world due to their advances in economics and modern technologies. Today it is American English that possesses a unique status in forming an international English norm. The following factors promoted American Engish:

- Its population (Among the native English speakers Americans count as $70 \%$ compared to $17 \%$ of British English speakers of the total number);

- The numerical superiority of higher education institutions in the United States in comparison with the United Kingdom;

- A high spread of the US printing industry;

- An international influence of the American media and IT;

- The impact of American pop culture on the language and lifestyle of the entire globe;

- The importance of economic situation in the United States.

Moreover, analyses of American slang unites will be of use to many English learners since English is now considered a global language. Many people see knowledge of American English as their goal, and an ability to use and understand its slang in its modern and past variant, presented in the last century, will for sure bring them closer to their goal.

Diachronic Change of American Slang over the Last 65 Years. Logically, many slang words and units have been transformed over time the last century. They either completely changed their meanings or changed them to certain extend. For example, to be up meant "to be happy" in the $60^{\text {th }}$, but then transformed its meaning into "to be late" in the $80^{\text {th }}$. There are cases when the meaning stays the same, but the word changes its graphical form. It can be seen in the pair what the frig used in the $50^{\text {th }}$ and what the frick used in the $80^{\text {th }}$. Though they mean the same thing they are written differently. But if we analyze this pair in Google books Ngram Viewer, we get that the "frig" form was always more popular then "frick", even during the $80^{\text {th }}$ (fig. 1).

Trying to analyze it further we looked both ways of writing in Corpus of Historical American English (fig. 2). There we can see that the word "frick" actually was quite popular about that time, but mostly not because of its slang meaning, but because of the Frick Museum and a name of a character in the play "Red Emma". "Frig", according to the corpus being not so popular, was still used in its slang meaning (How're your plans for getting that frig? Ah, frig' em).

It can also happen that the slang word will be revived. Let us illustrate it with the example on the word "armpit". Originally it means a part of a human body (a drop of sweat from his left armpit). In its slang variant it means an unpleasant place (Then it set off in a new direction and disappeared into a dark armpit). In that meaning it was mostly used 
in the $50^{\text {th }}$ and $60^{\text {th }}$, as we can judge by the dictionary and the information in the corpus. But it happens that modern authors use words with outdated slang meaning. So, Cizmar Paula, the author of "Pretty Places" used "armpit" in its old slang meaning: This is an armpit place. This is a nightmare place.

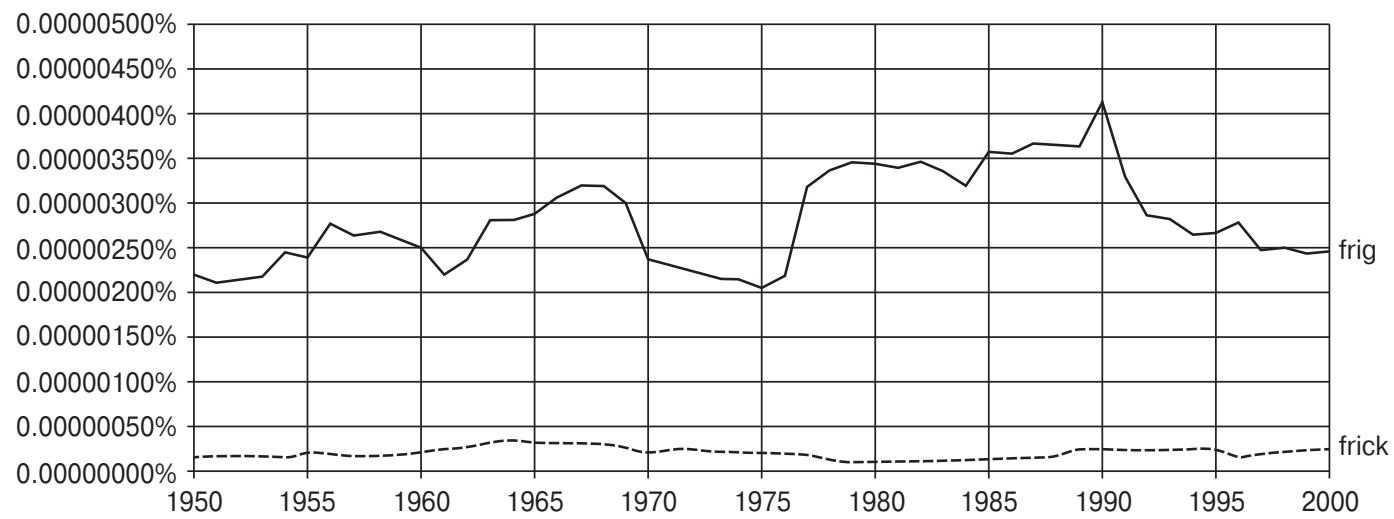

Fig. 1. Analyzing words "frig" and "frick" in Google Ngram Viewer

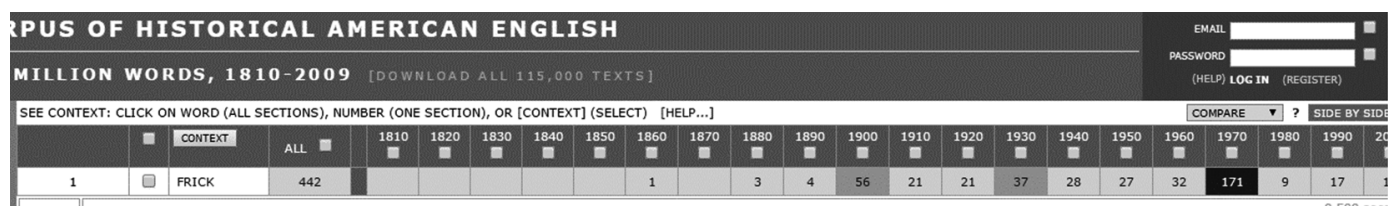

Fig. 2. Analysis of the word "frick" from the "Corpus of Historical American English"

What is also of interest about the slang meaning of "armpit" is that though it itself is not frequently used these days, it is left in idioms. We still can get across it in the idiom "the armpit of smth": The armpit of New England had become the renaissance city. There are some slang words whose frequency of usage does not radically change through time. These words were popular in the $50^{\text {th }}$ and they are still around us these days. Let us examine the frequency of usage of the slang idiom "on cloud seven" (fig. 3).

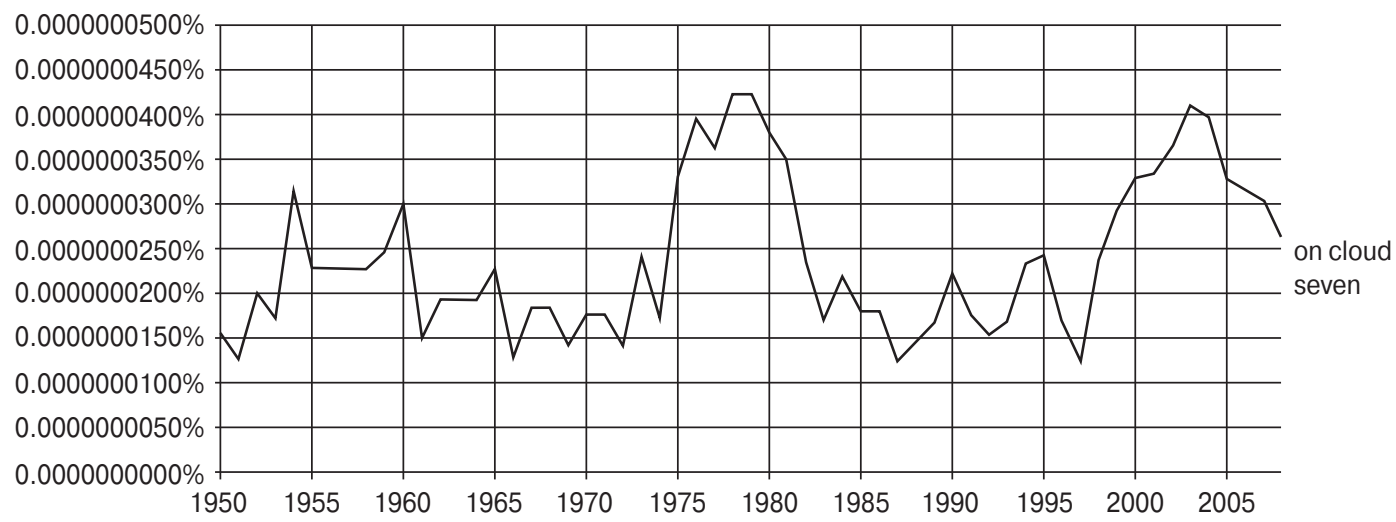

Fig. 3. The frequency of using the slang idiom "on cloud seven" 
Some slang words changed their meaning only slightly and became more specific. Nerds who are now strongly associated with computers originally were just unattractive, unsociable and with strange hobbies. The original slang meaning appeared in early $50^{\text {th }}$ and naturally computers were not such a usual thing as it is now. But then the meaning became more peculiar. Despite the reduction of a sphere of application in its "reduced" meaning the word became far more popular. Its reason is the popularity of everything connected with computers in general (fig. 4).

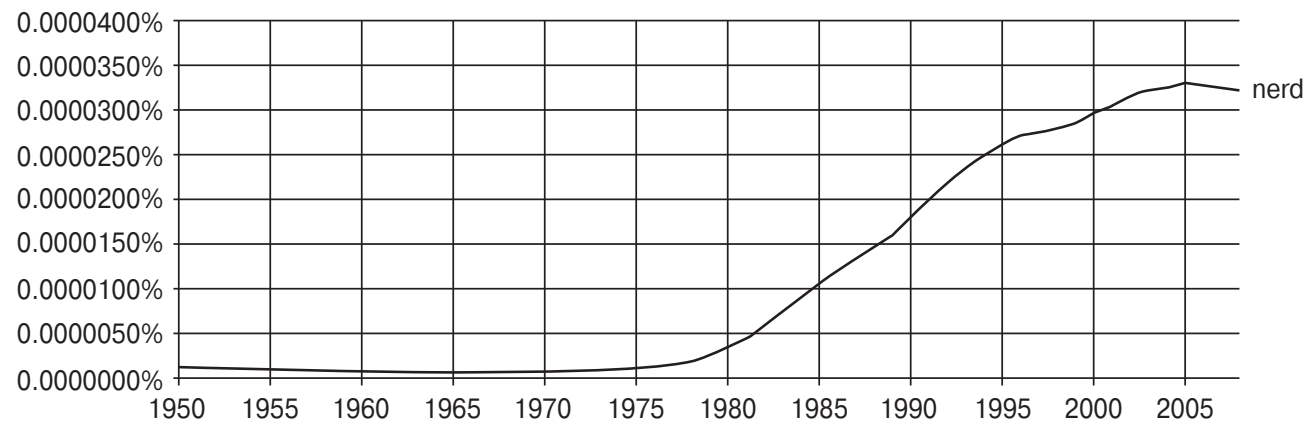

Fig. 4. Display of a popularity of computer subjects slang terms

It is important to point out that old people who come to know the particulars of modern technologies, social networks and mass media issues usually do not have problems with modern widespread slang. They may lack knowledge of some specific slang, such as slang of students, but on the whole they can understand younger generations. People who do not have troubles with communication with youngsters at all are those who do that on general occasion. They are mostly people with many children and grandchildren and spend a lot of time with them or social workers specializing in children care.

Younger and "middle" generation who are fluent in old-styled slang are far less common. It is always easier to borrow language peculiarities of the same social group as these are the people you see most often. To get into that old variant of slang the person has to have either a specific hobby (it might be an interest in linguistics) or a specific job (social workers of houses for aged). Usually people who can easily understand slang of the elder generation are either philologists or well-bred and educated ones.

The problem connected with old slang words is that it is quite difficult to find them. They could be generally in use among the young generation, but we cannot find it in books, songs, films, play scrips. The reason is that at that time the system of censorship was extremely strict. All scripts and song lyrics were thoroughly checked, so it all sounded more like a literary language then a colloquial speech. So even in the corpus we cannot find all the information which would reflect the situation in the language for sure. That is why it is so important to make polls, interview the elder generation and compile special slang dictionaries.

With the increasing possibilities of communication there is a need for abbreviations and catchy slang units that can express emotions in a short but colorful way. So it is possible to explain the fact that now in the world slang units are used far more than some decades ago. Moreover, some slang units were adopted from other languages. Especially, 
this phenomenon became apparent after English became the language of the Internet. Slang has changed and continues to change as a consequence of the development of mass media. New cultural phenomena generate a need for new kinds of verbal manifestation of emotions. Words often used on television or in cinema tend to get into the language and in rare cases to remain there for years. The twentieth century was very intense. Full of new trends, subcultures, discoveries and development. Twenty-first century perfectly keeps up with it. If earlier slang could live a decade, it is now rare for a "buzzword" to stay in use longer than for a year.

Its study is highly important because it not only allows us to trace the development of slang, but also helps to narrow the generation gap. We sometimes do not realize that the elder generation speaks about. We think their words are strange, like strange sayings. Our grandparents, in their turn, believe our modern language is barbaric and uneducated. But studying the language of each other we as well start to understand each other better.

\section{LITERATURE}

[1] Захаров В.П. Веб-пространство как языковой корпус. URL: http://dok.opredelim.com/docs/ index-37955.html (дата обращения: 13.06.2017)

[2] Burke D. Street Talk. How to Speak \& Understand American Slang. Los Angeles: Optima Books, 1993. $270 \mathrm{p}$.

[3] Lighter J.E. Random House Historical Dictionary of American Slang. N.Y.: Random House, 1994. $387 \mathrm{p}$.

[4] Zaharov V.P., Masevich A.C. URL: https://books.google.com/ngrams/info

[5] Michael McCarthy. English Vocabulary in Use. Cambridge University Press, 2003. 316 p.

[6] Spears R. Slang and Euphemism. A dictionary of oaths, curses, insults, ethnic slurs, sexual slang and metaphor, drug talk. N.Y.: A Signet Books, 2001. 390 p.

[7] Kerimbaeva B.T., Iskakova P.K. Psychological aspects of training with using of modern information technologies // Global Science and Innovation: materials of the IV international scientific conference. March 12-13th. Chicago, USA, 2015. Pp. 320-324.

(C) Nardyuzhev V.I., Nardyuzhev I.V., Marfina V.E., Kurinin I.N., 2017

Article history:

Received: July 20, 2017

Accepted: August 30, 2017

For citation:

Nardyuzhev V.I., Nardyuzhev I.V., Marfina V.E., Kurinin I.N. (2017). American Slang: Diachronic Analysis. RUDN Journal of Informatization Education, 14 (4), 399-405. DOI 10.22363/23128631-2017-14-4-399-405

\section{Bio Note:}

Nardyuzhev Viktor Ivanovich, candidate of engineering sciences, associate professor of the department "Computer technologies" of the philological faculty of the Peoples' Friendship University of Russia. Contact Information: e-mail: vin111@mail.ru

Nardyuzhev Ivan Viktorovich, candidate of engineering sciences, programmer of the software development department of JSC "The Seventh Continent". Contact Information: e-mail: inard@ rambler.ru 
Marfina Victoria Evgenievna, student of the master course at the department of comparative educational policy of the Peoples' Friendship University of Russia. Contact information: e-mail: vika434221@gmail.com

Kurinin Ivan Nikolayevich, candidate of economic sciences, associate professor, head of the department "Computer technologies" of the philological faculty of the Peoples' Friendship University of Russia. Contact Information: e-mail: kurinin_in@pfur.ru

\title{
АМЕРИКАНСКИЙ СЛЕНГ: ДИАХРОНИЧЕСКИЙ АНАЛИЗ
}

\author{
В.И. Нардюжев ${ }^{1}$, И.В. Нардюжев ${ }^{2}$, В.Е. Марфина ${ }^{1}$, И.Н. Куринин ${ }^{1}$ \\ ${ }^{1}$ Российский университет дружбы народов \\ ул. Миклухо-Маклая, 6, Москва, Россия, 117198 \\ 2 Департамент разработки программного обеспечения ОАО «Седьмой континент» \\ n. Московский, д. Говорово, 47 км МКАД, стр. 2, Москва, Россия, 142784
}

Данная работа посвящена диахроническому анализу американского сленга. В настоящее время английский язык признан «глобальным языком», и его американский вариант в свою очередь сильно влияет на международную норму. Чтобы правильно использовать и понимать язык, нельзя забывать о его сленговой составляющей. Являясь знаменательной частью языка, отражающего его культуру и историю, сленг меняется с годами. Для преодоления разрыва поколений такое исследование, как диахронический анализ сленга, имеет большое значение.

Ключевые слова: сленг, американский английский, американский сленг, диахрония, диахронический анализ, исторический корпус американского английского

\section{REFERENCES}

[1] Zaharov V.P. Veb-prostranstvo kakjazykovoj korpus [Web space as a linguistic corpus]. URL: http:// dok.opredelim.com/docs/index-37955.html

[2] Burke D. Street Talk. How to Speak \& Understand American Slang. Los Angeles: Optima Books, 1993. $270 \mathrm{p}$.

[3] Lighter J.E. Random House Historical Dictionary of American Slang. N.Y.: Random House, 1994. $387 \mathrm{p}$.

[4] Zaharov V.P., Masevich A.C. URL: https://books.google.com/ngrams/info

[5] Michael McCarthy. English Vocabulary in Use. Cambridge University Press, 2003. 316 p.

[6] Spears R. Slang and Euphemism. A dictionary of oaths, curses, insults, ethnic slurs, sexual slang and metaphor, drug talk. N.Y.: A Signet Books, 2001. 390 p.

[7] Kerimbaeva B.T., Iskakova P.K. Psychological aspects of training with using of modern information technologies // Global Science and Innovation: materials of the IV international scientific conference. March 12-13th. Chicago, USA, 2015. Pp. 320-324.

\section{История статьи:}

Дата поступления в редакцию: 20 июня 2017

Дата принятия к печати: 30 августа 2017

\section{Для цитирования:}

Нардюжев В.И., Нардюжев И.В., Марфина В.Е., Куринин И.Н. Американский сленг: диахронический анализ // Вестник Российского университета дружбы народов. Серия «Инфор- 
матизация образования». 2017. T. 14. № 4. С. 399-405. DOI 10.22363/2312-8631-2017-144-399-405

Сведения об авторах:

Нардюжев Виктор Иванович, кандидат технических наук, доцент кафедры «Компьютерные технологии» филологического факультета Российского университета дружбы народов. Контактная информация: e-mail: vin111@mail.ru

Нардюжев Иван Викторович, кандидат технических наук, программист департамента разработки программного обеспечения ОАО «Седьмой континент». Контактная информация: e-mail: inard@rambler.ru

Марфина Виктория Евгеньевна, студентка магистратуры кафедры «Сравнительной образовательной политики» Российского университета дружбы народов. Контактная информация: e-mail: vika434221@gmail.com

Куринин Иван Николаевич, кандидат экономических наук, доцент, заведующий кафедрой «Компьютерные технологии» филологического факультета Российского университета дружбы народов. Контактная информация: e-mail: kurinin_in@pfur.ru 